Volume 3, No. 1, 102-113, April 2019

\title{
KEHIDUPAN PEREMPUAN NELAYAN DI GAMPONG UJONG BLANG KECAMATAN BANDA SAKTI KOTA LHOKSEUMAWE
}

\author{
Selpia Arwida Tanjung, Abdullah Akhyar Nasution \\ Program Studi Antropologi \\ Universitas Malikussaleh Lhokseumawe Aceh-Indonesia
}

\begin{abstract}
Abstrak : Pokok masalah yang diajukan dalam paper adalah perlunya meninjau kembali tentang kehidupan yang dijalani oleh perempuan-perempuan pencari tiram dan kontribusi ekonomi yang diberikan oleh mereka untuk perekonomian rumah tangga nelayan di Gampong Ujong Blang, Kecamatan Banda Sakti, Kota Lhokseumawe. Kota ini memiliki sumber daya alam laut yang melimpah sebagai wilayah pesisir, selayaknya dengan sumber daya alam yang ada dapat memberikan kesejahteraan bagi masyarakat yang menempati kota tersebut, terkhusus bagi keluarga yang berada di pesisir yaitu Gampong Ujong Blang. Penelitian ini menggunakan kajian antropologi ekonomi dengan metode kualitatif yang bersifat deskriptif. Hasil penelitian menunjukkan bahwa kontribusi yang diberikan oleh para perempuan pencari tiram sangat signifikan dalam meningkatkan kesejahteraan rumah tangga nelayan. Keberadaan mereka juga untuk mendukung pendapatan suami yang sangat terbatas dalam memenuhi kebutuhan rumah tangga. Bahkan, terkadang hasil yang didapat oleh perempuan melebihi dari pendapatan suami, tetapi ini semua tergantung bagaimana keahlian mereka dalam mengolah tiram pasca pencarian
\end{abstract}

Kata Kunci: Peran perempuan, keluarga, kemiskinan. 
Aceh Anthropological Journal, Vol. 3, No. 1, hlm: 102-113, April 2019

\section{A. Pendahuluan}

Indonesia merupakan negara kepulauan terbesar di dunia atau disebut sebagai (archipelagic state) yang memiliki panjang pantai sekitar $81.000 \mathrm{~km}$ dan 17.504 pulau (Sidharta, 2015:10). Indonesia terdiri dari lima pulau besar dan 30 pulau kecil, 8.651 pulau yang sudah bernama, dan 9.842 yang belum diverifikasi. Negara Republik Indonesia meliputi wilayah daratan dan wilayah air, dimana sebagian besar dari wilayah indonesia merupakan wilayah lautan yang meliputi 5,8 juta $\mathrm{km}$ atau 70\% dari luas total teritorial Indonesia (Retnowati, 2011: 149). Dengan luas wilayah perairan yang dimiliki, tentunya sangat menguntungkan bagi Bangsa Indonesia karena melimpah ruah kekayaan alam yang dimiliki dan dikandungnya. Maka tidak salah bila indonesia dijuluki sebagai negara zamrud khatulistiwa. Kondisi dimana istri ikut berperan aktif untuk menstabilkan ekonomi rumah tangga, dengan sumber daya laut yang ada seharusnya masyarakat di Gampong Ujong Blang dapat hidup sejahtera. Tetapi pada keyataannya karakteristik masyarakat Ujong Blang dalam pengamatan penulis, sangat cocok dibahas dengan menggunakan penuturan oleh Wan Zulkarnain kemiskinan relatif, sebenarnya telah hidup diatas garis kemiskinan, namun masih berada di bawah kemampuan masyarakat sekitar (Zulkarnain, 2006: 25).

Dimana dalam pengamatan penulis para perempuan nelayan/istri-istri nelayan di Gampong Ujong Blang harus ikut (meramu) mengumpulkan tiram, lalu dijual, kemudian hasil penjualan tersebut secara langsung menjadi penstabil ekonomi keluarga untuk dapat memenuhi kebutuhan sehari-hari baik berupa pangan, sandang serta papan disaat hasi laut tidak dapat diharapkan. Di samping sebagai seorang pencari tiram, kaum perempuan ini juga melakukan aktivitasnya sebagai seorang ibu rumah tangga.

Oleh karena itu, rumusan masalah yang ingin dijawab dalam tulisan ini adalah apa dan bagaimana sebenarnya kontribusi ekonomi yang diberikan oleh perempuan pencari tiram pada perekonomian rumah tangga nelayan di Gampong Ujong Blang, Kecamatan Banda Sakti, Kota Lhokseumawe. 
Aceh Anthropological Journal, Vol. 3, No. 1, hlm: 102-113, April 2019

\section{B. Metode Penelitian}

Penelitian ini dilaksanakan di Gampong Ujong Blang, Kecamatan Banda Sakti, Kota Lhokseumawe, Aceh. Hal ini ditentukan sebagai lokasi penelitian karena didasarkan atas beberapa alasan, dimana di gampong ini merupakan salah satu kawasan maritim di wilayah pesisir di Kota Lhokseumawe. Alasan pertama adalah karena di kawasan ini banyak ditemukan para perempuan pencari tiram dimana mereka memanfaatkan sumber daya alam yang ada untuk dapat memenuhi kebutuhan keluarga. Kedua dari unsur keterjangkauan lokasi penelitian dengan penulis, hal ini dilihat dari segi tenaga, dana, maupun dari segi efesiensi waktu. Sehingga memudahkan penulis dalam melakukan penelitian dilokasi tersebut, selain itu penulis dapat melakukan observasi lebih sering dengan masyarakat yang diteliti, cara ini lebih efektif dalam membangun raport yang baik di masyarakat.

Pendekatan penelitian ini menggunakan kajian antropologi ekonomi dengan metode sosial kualitatif yang bersifat deskriptif dengan teknik observasi, wawancara mendalam, studi dokumentasi, studi kepustakaan pengumpulan informasi terhadap key informan (informan kunci) yang kemudian di observasi langsung kelapangan agar mendapatkan sumber data yang diharapkan.

Secara umum data yang digunakan dalam penelitian ini dibagi menjadi dua bagian yaitu: Data Primer yaitu data yang berasal dari sumber data lapangan penelitian. Sumber data tersebut terdapat pada hasil observasi dan hasil wawancara yang dilakukan kepada informan. Data Sekunder yaitu data-data yang didapat melalui dokumentasi dan literatur-literatur yang berhubungan dengan penelitian seperti halnya buku, surat kabar, jurnal-jurnal hasil penelitian yang bersangkutan dengan tema proposal penelitian. Adapun informan penelitian yang penulis lakukan terbagi menjadi dua yaitu informan kunci (key informan) adalah mereka yang mengetahui dan memiliki berbagai informasi pokok yang diperlukan dalam penelitian ialah para perempuan pencari tiram yang ada di Gampong Ujong Blang serta informan tambahan yaitu mereka yang dapat memberi informasi walaupun tidak langsung terlibat dalam interaksi sosial yang diteliti.

Tehnik pengumulan data yang penulis lakukan disini ialah yang pertama, observasi dengan cara melakukan pengamatan terhadap objek penelitian penuis baik itu lokasi penelitian, dan objek penelitian. Kedua, wawancara merupakan 
Aceh Anthropological Journal, Vol. 3, No. 1, hlm: 102-113, April 2019

percakapan yang dilakukan oleh dua pihak yaitu pewawancara yang mengajukan pertanyaan kepada terwawancara dengan maksud tertentu.Ketiga, Studi dokumen dibagi kedalam dua bagian yakni dokumen pribadi dan dokumen resmi. Dokumen pribadi merupakan catatan atau karangan seseorang secara tertulis mengenai tindakan, pengalaman dan kepercayaannya. Sedangkan dokumen resmi adalah sumber data tertulis yang diperoleh dari dalam lokasi penelitian (dokumen internal) maupun dari luar desa (dokumen eskternal).

\section{Landasan Teoretis}

Dalam konsep struktural-fungsionalisme model yang dapat digunakan adalah model organisme tubuh manusia. Radcliffe-Brown mengumpamakan sebuah masyarakat sebagai sebuah organisme tubuh manusia, dan kehidupan sosial adalah seperti kehidupan organisme tubuh tersebut. Satu organisme tubuh terdiri dari sekumpulan sel dan cairan yang tersusun dalam suatu jaringan hubungan, sedemikian rupa, sehingga membentuk sebuah keseluruhan kehidupan yang terintegrasi. Susunan hubungan antara unit-unit dalam organisme tersebut, atau sistem hubungan yang mengikat keseluruhan unit, disebut struktur dari organisme (Marzali, 2006: 129).

Struktural-fungsional adalah penggabungan dari dua pendekatan fungsional Durkheim kemudian digabungkan dengan pendekatan struktural Radclife-Brown. Karena memahami penekatan struktural-fungsional, orang harus melihat dulu sejarah perkembangan pendekatan fungsional. Struktural-fungsional adalah untuk membagun suatu sistem sosial, atau struktur sosial, melalui pengajian terhadap pola hubungan yang berfungsi antara individu-individu, antara kelompok-kelompok, atau antara institusi-institusi sosial di dalam suatu masyaraka, pada suatu kurun masa tertentu (Marzali, 2006: 128).

Adapun pengertian peran perempuan yang terjadi di masyarakat indonesia pada umumnya pembagian kerja antara lelaki dan perempuan menggambarkan peran perempuan. Basis pembagian kerja menurut jenis kelamin ini tidak diragukan lagi terkait dengan keadaan peran lelaki dan perempuan dalam fungsi reproduksi. Dalam masyarakat mempresentasikan peran perempuan dapat dilakukan dari 
Aceh Anthropological Journal, Vol. 3, No. 1, hlm: 102-113, April 2019

presfektif posisi mereka dalam berurusan dengan pekerjaan produktif tidak langsung domestik dan pekerjaan produktif publik (Ahdiah, 2013: 1087).

Friedman memberikan pengertian tentang keluarga ialah sekumpulan orang-orang yang tinggal bersama dalam satu rumah yang dihubungkan satu ikatan perkawinan, hubungan darah yang bertujuan mempertahankan budaya umum dan meningkatkan perkembangan fisik, mental, emosional, dan sosial dari tiap anggota.

Kontribusi ekonomi adalah keikutsertaan perempuan dalam mencari nafkah akan membawa dampak positif yaitu adanya peningkatan terhadap struktur sosial dalam keluarga seperti keuangan, kepemilikan barang mewah, dan standar hidup yang lebih tinggi dengan mencapai rasa aman yang lebih baik sehingga berdampak pada peningkatan status sosial keluarga. Dimana pembagian kerja antara sesama anggota keluarga (laki-laki dan perempuan) dalam keluarga inti menunjukkan adanya differensiasi gender yang merupakan satu prasyarat struktural untuk keberlangsungan keluarga inti. Kerja sama antara suami istri yang semakin baik akan meningkatkan kesejahteraan keluarga yang diharapkan (Puspitasari, 2013:11).

\section{Pembahasan}

\section{Perempuan di Ujong Blang}

Perempuan di Gampong Ujong Blang sama saja dengan perempuan Aceh pada umumnya. Jika berbicara tentang perempuan Aceh secara umum, tentu tidak bisa terlepas dari sejarah panjang yang dimilikinya. Dimulai dari masa penjajahan dimana perempuan Aceh dianggap sebagai sultanah, pahlawan dan pemimpin yang hebat. Lalu pada masa konflik berkepanjangan hingga masa bencana Tsunami, Presiden secara Nasional sudah menginstruksikan pengarusutamaan gender di Aceh membuat sebuah percepatan tersendiri terhadap penetrasi isu gender ke dalam masyarakat (Srimulyani, 2009: 8).

Padahal secara adat, perempuan Aceh memiliki posisi yang cukup kuat di dalam keluarga. Tidak sedikit ditemui di desa-desa, terdapat suami-suami yang merantau ke luar daerah untuk bekerja yang pada gilirannya memposisikan perempuan sebagai pemilik rumah seutuhnya serta menunjukkan andil perempuan yang tinggi dalam Management keluarga. Hal ini juga berimbas pada kurang 
interaksi dan keterkaitan secara psikologis antara seorang ayah dan anakanaknya.Kondisi ini semakin mempaerkuat "tradisi matrelinial" dikalangan masyarakaat Aceh. Dimana Mereka cenderung melakukan perannya sebagai ibu rumah tangga sekaligus pekerja di luar rumah yang turut membantu perekonomian keluarga. Tradisi ini menempatkan perempuan dalam kedudukan sosial yang kuat sekaligus memberi mereka otoritas secara budaya di tingkat desa (Srimulyani, 2009: 6). Hal ini serupa dengan apa yang terjadi pada perempuan-perempuan pencari tiram di Gampong Ujong Blang.

Kondisi perekonomian nelayan tradisional yang berada di kelas terbawah masyarakat Ujong Blang membuat posisi perempuan di keluarga tidak lagi sebatas menjalankan perannya sebagai ibu, isteri atau anak perempuan. Mereka mau tak mau juga harus terlibat dalam memaksimalkan kondisi perekonomian keluarga, sehingga sebagian besar dari mereka telah mengakses ranah publik sebagaimana yang dilakukan laki-laki yakni dengan bekerja. Pekerjaan mencari tiram adalah aktivitas yang paling banyak dilakukan perempuan Ujong Blang pengaruh kebijakan "ibuisme negara" yang marak direalisasikan lewat program-prorgam seperti Dharma Wanita dan Pemberdayaan Kesejahteraan Keluarga (PKK) di masa pemerintahan Soeharto juga mengikis tradisi matrilokal yang ada di Aceh (Srimulyani, 2009: 9).

Namun nyatanya di Ujong Blang sendiri, peran perempuan tidak lagi dibatasi sebagai sosok ibu atau isteri yang hanya bertugas mengurusi anak-anak. Posisi lakilaki tetap menjadi kepala keluarga, hanya saja perempuan di Ujong Blang tidak lagi dibatasi pergerakannya. Mereka dibiarkan turut andil dalam membantu perekonomian keluarga lewat aktivitas-aktivitas yang menghasilkan pendapatan. Seperti misalnya, berdagang, bekerja sebagai pegawai swasta maupun PNS dan satu diantara sekian profesi yang banyak diemban perempuan Ujong Blang adalah sebagai pencari tiram.

\section{Kontribusi Ekonomi Perempuan Pencari Tiram pada Perekonomian Rumah Tangga}

Secara umum masyarakat nelayan dianggap sebagai salah satu lapisan masyarakat dengan tingkat kesejahteraan yang masih rendah. Tentu, tidak semua kaum nelayan dapat dikatakan berada dalam garis kemiskinan, banyak juga 
nelayan-nelayan yang digolongkan sejahtera seperti nelayan pemilik kapal dan pemilik modal misalnya. Sementara pada masyarakat Ujong Blang sendiri ada sebutan untuk lapisan nelayan sejahtera yang notabene kaum pemilik modal yakni "toke". Serupa dengan tengkulak, mereka adalah kaum yang menampung hasil tangkapan nelayan-nelayan kelas bawah dengan kesepakatan harga tertentu lalu menjualnya ke pasar dengan harga lebih tinggi. Lapisan berikutnya yang masih bisa dikategorikan sebagai kaum nelayan sejahtera adalah para kapten kapal dan pawang kapal. Kapten adalah orang yang memimpin kapal saat sebuah kapal melakukan ekspedisi pencarian ikan atau melaut.

Akan tetapi, dalam struktur sosial ekonomi masyarakat nelayan sendiri masih terdapat lapisan yang dikategorikan belum sejahtera dan berada di bawah kelas nelayan-nelayan pemilik modal (toke), kapten maupun pawang yang ada di dalam masyarakat Gampong Ujong Blang.Seperti misalnya nelayan tradisional dan nelayan buruh yang masih dianggap sebagai salah satu lapisan masyarakat dengan tingkat kesejahteraan yang rendah. Data Badan Pusat Statistik (BPS) Indonesia mencatat jumlah nelayan miskin pada tahun 2011 adalah sebanyak 7,87 juta orang atau 25, 14\% dari total masyarakat miskin nasional. Sementara data Program Perlindungan Sosial 2014 menyatakan bahwa dari 16 juta rumah tangga kesejahteraan rendah, 30\% nya adalah rumah tangga yang menggantungkan pendapatannya dari aktivitas penangkapan ikan. Sementara berdasarkan Survey Sosial Ekonomi Nasional pada tahun 2013 menyebutkan 71,2\% nelayan berpendidikan sekolah dasar ke bawah (Listiyandra, 2016: 81).

Fakta-fakta diatas sejalan dengan realitas masyarakat nelayan kalangan bawah di Gampong Ujong Blang. Nelayan buruh atau tradisional tidak memiliki pemasukan yang tetap dan mencukupi sehingga isteri-isteri mereka pun mau tak mau mengambil peran ganda yakni sebagai pengurus rumah tangga sekaligus tenaga yang bekerja disektor publik guna memenuhi kecukupan pendapatan keluarga. Perempuan pencari tiram yang ada di gampong ini, merupakan para perempuan yang mengalami kondisi ekonomi menengah ke bawah, yang berada di atas garis kemiskinan namun berada di bawah kemampuan masyarakat sekitar, mereka sudah dapat memenuhi kebutuhan pangan, papan, dan sandang. Namun mereka masih mengalami kesulitan dalam hal pendidikan anak, dibuktikan dengan 
Aceh Anthropological Journal, Vol. 3, No. 1, hlm: 102-113, April 2019

rendahnya pendidikan yang mereka dapatkan ada yang hanya tamat SD saja, ada yang tidak tamat SD bahkan tidak sedikit juga putus sekolah di tengah jalan.

Kondisi perekonomian masyarakat yang seperti ini juga turut memicu tidak tercapainya kesehatan yang terjamin bagi mereka. Walau, pemerintah telah menyediakan asuransi kesehatan gratis namun ada masa di mana mereka berada di situasi sakit yang tidak bisa sepenuhnya ditanggung oleh BPJS. Maka, anggota keluarga menengah ke bawah yang notabene adalah nelayan ini harus memikirkan jalan keluar lain, dalam menanggulangi kebutuhan yang tidak bisa terpenuhi dengan pendapatan utama tersebut. Jadi, di sinilah hadir para perempuan-perempuan pencari tiram yang turut berkontribusi menstabilkan perekonomian rumah tangga.

Adapun konstribusi perempuan pencari tiram disini ialah keikutsertaan, keterlibatan, melibatkan diri maupun sumbangan perempuan dalam mencari nafkah akan membawa dampak positif yaitu adanya peningkatan terhadap struktur sosial keluarga. Dimana banyak perempuan di Gampong Ujong Blang ini yang bekerja di sektor publik yang menghasilkan uang untuk menambah penghasilan keluarga. Hal ini dilakukan untuk menghadapi tekanan ekonomi dan kebutuhan rumah tangga.

\section{Kontribusi Ekonomi Isteri}

Konstribusi ekonomi perempuan pencari tiram pada perekonomi pada keluarganya yang berstatus sebagi sorang istri, ialah dengan mengerjakan pekerjaan di ranah publik untuk menstabilkan kebutuhan dalam rumah tangga. Dimana dengan cara mencari tiram lalu dijual perempuan ini dapat membeli kebutuhan rumah tangga, serta memberikan jajan bagi anaknya baik sebelum maupun setelah pulang sekolah. Hal ini dapat dilakukan oleh para perempuan ini karena andil dalam membagi waktu di dalam mengurus rumah tangga.

Setelah perempuan ini mengerjakan perkerjaannya pada ranah domestiknya, maka mereka akan mengerjakan mencari tiram. Dimana 43 perempuan pencari tiram yang berstatus sebagai seorang ibu juga memberikan kontribusi tenaganya, dari pagi hari untuk mencari tiram dengan waktu yang digunakan 3-4 jam didalam air, baik di waduk maupun di sungai Los Kala dengan mendapatkan hasil pencarian tiram sebanyak satu karung yang berukuran $25 \mathrm{Kg}$. 
Aceh Anthropological Journal, Vol. 3, No. 1, hlm: 102-113, April 2019

Kemudian para peremuan ada yang menjual dalam keadaan blum dikupas dari kulitnya dan ada juga yang menjual hasil tiramnya saja. Dimana satu karung berukuran $25 \mathrm{~kg}$ itu mendapatkan 10-12 bungkus tiram dengan harga jual Rp. 10. 000 per bungkus dan apabila hasil dagangan mereka habis perempuan pencari tiram ini mendapatkan Rp 100-120 per harinya.

Pendapatan yang mereka dapatkan akan mereka kontribusikan sebanyak (70 \%) setiap kali mencari tiram, yang mana jika mereka mendapatkan Rp 100 mereka memberikan tujuh puluh ribu rupiah dan tiga puluh ribu rupiah akan mereka simpan. Dimana mereka akan menggunakannya pada saat mereka sedang tidak mencari tiram. Adapun faktor-faktor yang menyebabkan para perempuan ini tidak melakukan pencarian tiram pada saat terjadinya air pasang, hujan, tidak musim tiram, sakit, anak sakit, orang meninggal dikampung, serta adanya pesta.

\section{Kontribusi Ekonomi Janda}

Perempuan yang berstus janda disini melakukan pekerjaan juga diranah publik, dimana perempuan ini juga berperan sebagai kepala rumah tangga. Dikerenakan peran serta status yang disandangnya membuat perempuan ini harus memenuhi kebutuhan kebutuhan seluruh keluarga baik itu kebutuhan dapur, sandang, dan papan layaknya seorang kepala rumah tangga memenuhi nafkah. Namun disini seorang janda yang memiliki juga mengerjakan tugasnya sebagai seorang ibu yaitu merawat, menjaga, serta memberikan nilai-nilai maupun normanorma yang baik bagi anak-anaknya, karena baik buruknya seorang anak tergantung pada pola pengasuhan yang dilakukan atau diberikan oleh orang tua.

Sama lahnya dengan sorang istri, janda yang berperan juga sebagi seorang istri juga melakukan pekerjaannya diranah domestiknya, lalu perempuan ini akan melakukan pekerjaan diranah publik untuk memenuhi kebutuhan perekonomian rumah tangganya. Dimana hasil yang didapatkan oleh seorang janda begitu pula dengan rentang waktu yang digunakan sama dengan yang dilakukan oleh seorang istri. Namun terdapat perbedaan diantara mereka yaitu pada konstribusi ekonomi yang diberikan. Jika, perempuan yang berstatus meyumbangkan sebanyak (70\%) untuk keluarganya, disini sebagai janda ia memberikan pendapatnya sebanyak 
Aceh Anthropological Journal, Vol. 3, No. 1, hlm: 102-113, April 2019

(100\%) yaitu sekitar Rp100-120 yang mana jika dagangannya habis semua. Bahkan perempuan ini tidak ada simpanan pendapatan ketika tidak pergi mencari tiram.

Adapun hal yang dilakukan ketika ada faktor penghambat perempuan ini dalam mencari tiram yaitu saat anaknya sakit. Para perempuan ini tidak pergi untuk mencari tiram, mereka akan meminjam uang pada kerabat terdekat mereka. dan pada saat anak mereka tidak sakit mereka akan menitipkan anak kecil kepada kerabatnya ataupun kepada orang lain seperti tetangga dengan cara memberi imbalan berupa uang. Kondisi pada saat berjualan mereka akan membawa anak kecil tersebut karena mereka berjualan ditepi jalan, bahkan tidak banyak yang letak penjualannya jauh dengan rumah mereka, para perempuan ini menyiapkan tempat tidur bagi anak-anaknya salah satunya seperti ayunan.

\section{Kontribusi Ekonomi Anak atau Gadis}

Seorang anak merupakan tanggung jawab dari orang tua baik kebutuhan pangan, papan, dan sandang. Namun dikarenakan keadaan orang tua dari anak yang melakukan pencari tiram ini kurang stabil, mengakibatkan seorang anak ikut serta memenuhi kebutuhannya sendiri maupun keluarganya. Melihat apa yang dilakukan orang tuanya ia pun ikut pergi bersama ibunya dalam mencari tiram. dari hasil wawancara dengan informan beliau mengatakan bahwa saat mencari tiram penampilannya sama saja dengan perempuan pencari tiram lainnya, tidak ada perbedaan, bahkan tidak malu dalam melukan pekerjaan ini.

Konstribusi ekonomi yang diberikan sorang anak yang melakukan pekerjaan mencari tiram, ia memberikan (40 \%) yaitu sekitar Rp 40-50 setiap dia pergi mencari tiram, dan biasanya dia akan menjual sendiri hasil tiramnya tidak ada istilah jual langsung. Kemudian pendapatan sekitar (40\%) digunakan untuk membeli kebutuhan seperti baju, bedak serta make up lainnya yang ia perlukan dan sisanya akan disimpan yang mana ia kan menggunakan uang tersebut untuk kebutuhannya pada saat tidak pergi mencari tiram serta jika semua kebutuhannya sudah terpenuhi ia mangatakan ia akan menyimpan untuk membeli barang berharga seperti cincin untuk tabungan.

Tiram-tiram ini jika dijual langsung dengan kulitnya mendapatkan uang sebesar Rp. 40.000,- yang mana akan dipotong ongkos becak sebesar Rp. 5000.- 
selain itu untuk lokasi yang berada di Lapang mereka mendapatkan tiga karung berukuran dua puluh lima kilo dengan harga jual langsung 80 ribu per karungnya. Dengan rentang waktu yang digunakan selama empat sampai lima jam, waktu ini belum termasuk dihitung untuk waktu pulang pergi mereka, Serta mereka harus membayar ongkos sebesar empat puluh ribu rupiah per orang.

Sedangkan untuk perempuan pencari tiram dengan tipe dua baik lokasi maupun waktu sama dengan perempuan pencari tiram tipe satu. Namun perbedaannya ialah pada perempuan pencari tiram tipe dua ini menjual tiramnya dengan cara di kupas dari kulitnya lalu kemudian dibungkus dengan harga sepuluh ribu perbungkusnya. Dimana jika para perempuan mencari tiram mendapatkan hasil lima belas kilo di Lokasi Los Kala Serta Waduk, satu karung tersebut dapat sepuluh bungkus tiram siap jual. Sedangkan perempuan yang mencari di Lapang ukuran karung dua puluh lima kilo tersebut mendapatkan tiram siap jual sebanyak dua puluh sampai dua puluh tiga bungkus

\section{E. Kesimpulan}

Kontribusi yang diberikan oleh perempuan pencari tiram dari aktivitas mereka secara ekonomis nyatanya memberi pengaruh yang cukup signifikan terhadap kondisi perekonomian rumah tangga nelayan. Pendapatan suami yang hanya Rp. 100.000 dalam dua atau tiga hari melaut nyatanya tidak dapat mengcover seluruh kebutuhan keluarga. Aktivitas mencari tiram yang dilakukan oleh para isteri disini ternyata justru menghasilkan pendapatan yang lebih jika dibandingkan dengan suami. Dalam satu kali mencari, perempuan pencari tiram dapat menghasilkan sekitar Rp. 35.000 hingga Rp. 540.000 tergantung kepada bagaimana pengolahan pasca pencarian yang mereka pilih serta lokasi pencariannya. Jika mereka langsung menjual hasil tangkapan tanpa diolah terlebih dahulu maka penghasilan yang diperoleh akan lebih sedikit dibandingkan dengan mereka yang mencari tiram, membersihkannya lalu memasarkannya sendiri. 
Aceh Anthropological Journal, Vol. 3, No. 1, hlm: 102-113, April 2019

\section{Daftar Pustaka}

Ahdiah, Indah. 2013. "Peran-Peran Perempuan Dalam Masyarakat". Jurnal Academica. Vol. 05. No.2.

Listiyandra, Krishna dkk. 2016. "Kontibusi Wanita Nelayan Dalam Upaya Pemenuhan Kebutuhan Ekonomi Keluarga Nelayan Di Muara Angke Kecamatan Penjaringan Jakarta Utara”. Jurnal Perikanan Kelautan, Vol. VII, No. 2.

Marzali, Amri. 2006. "Struktural-Fungsionallisme”. Antropologi Indonesia. Vol. 30, No.2.

Puspitasari, Novi dkk. 2013. "Peran Gender, Kontribusi Ekonomi Perempuan Dan Kesejahteraan Keluarga Petani Horikultural". Jurnal Keluarga Dan Konsumen. Vol. 6, No. 1.

Retnowati, Endang. 2011. "Nelayan indonesia dalam pusaran kemiskinan ekonomi (perspektif sosial, ekonomi dan hukum)". Perspektif. Volume XVI No 3.

Sidharta, Rahardjo Boy. 2015. Budaya Bahari dari Nusantara Menuju Mataram Moderen. Gosyen Publishing, Yogyakarta.

Srimulyani, Eka. 2009. Perempuan Dalam Masyarakat Aceh: Memahami Beberapa Persoalan Kekinian. Logica-Arti, Banda Aceh.

Zulkarnain,Wan. 2006. Permukiman Kumuh Di Perkotaan (Studi Kasus di Kelurahan Kampung Baru Kecamatan Medan Maimun Kota Medan. USU Press: Medan 